See discussions, stats, and author profiles for this publication at: https://www.researchgate.net/publication/330969381

\title{
The effects of servicescape on the emotional states and behavioural responses of hotel guests
}

Article in Anatolia · February 2019

DOI: 10.1080/13032917.2019.1575885

CITATIONS

4 authors, including:

Ali Avan

Afyon Kocatepe University

40 PUBLICATIONS 27 CITATIONS

SEE PROFILE

Ozcan Zorlu

Afyon Kocatepe University

44 PUBLICATIONS 67 CITATIONS

SEE PROFILE
READS

442

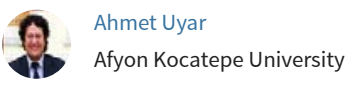

30 PUBlications 19 CItATIONS

SEE PROFILE

Some of the authors of this publication are also working on these related projects:

YEŞiL SATIN ALMA DAVRANIŞINI BELİRLEYEN UNSURLARIN YAPISAL EŞiTLİK MODELIYYLE İNCELENMESI View project

Effects of psychological empowerment practices on organizational silence View project 


\section{Anatolia}

\section{The effects of servicescape on the emotional states and behavioural responses of hotel guests}

\section{Ali Avan, Ahmet Uyar, Özcan Zorlu \& Alparslan Özmen}

To cite this article: Ali Avan, Ahmet Uyar, Özcan Zorlu \& Alparslan Özmen (2019) The effects of servicescape on the emotional states and behavioural responses of hotel guests, Anatolia, 30:3, 303-315, DOI: $10.1080 / 13032917.2019 .1575885$

To link to this article: https://doi.org/10.1080/13032917.2019.1575885

曲 Published online: 08 Feb 2019.

Submit your article to this journal $\pi$

Џ Article views: 170

Q View related articles ¿

View Crossmark data $[\pi$ 


\title{
The effects of servicescape on the emotional states and behavioural responses of hotel guests
}

\author{
Ali Avan (D) ${ }^{a}$, Ahmet Uyarb Özcan Zorlu ${ }^{c}$ and Alparslan Özmen ${ }^{d}$ \\ aDepartment of Tourism Management, Afyon Kocatepe University, Afyonkarahisar, Turkey; ${ }^{b}$ Department of \\ Banking and Insurance, Afyon Kocatepe University, Afyonkarahisar, Turkey; 'Department of Tourism Guidance, \\ Afyon Kocatepe University, Afyonkarahisar, Turkey; ${ }^{d}$ Department of Business, Afyon Kocatepe University, \\ Afyonkarahisar, Turkey
}

\begin{abstract}
The aim of this paper is to reveal the influence of servicescape of hotel businesses on the emotional states and behavioural responses of guests. Data collected from 211 participants, was tested by using Regression Analysis to determine the interaction among identified variables (servicescape, emotional states and behavioural responses). It was found that the servicescape component had a positive effect on behavioural responses, and emotional states of guests played a mediating role between servicescape and behavioural response components. It is important to determine what kind of emotional states along with the influence of servicescape result in behavioural changes in hotels. Hence, determining the emotional states that individuals experience in hotels will make it possible to design a servicescape by considering those emotional states.
\end{abstract}

\section{ARTICLE HISTORY}

Received 14 December 2017

Accepted 25 January 2019

\section{KEYWORDS}

Hospitality industry; servicescape; emotional states; behavioural responses; service encounter

\section{Introduction}

Studies dealing with the interaction between the variables of a servicescape and consumers reveal the potential of environmental components to influence the emotional states and behaviours of individuals (Ariffin, Bibon, \& Abdullah, 2011; Countryman \& Jang, 2006; Durna, Dedeoglu, \& Balikcioglu, 2015) and the influence of various environmental variables on behaviours (Mattila \& Wirtz, 2001; Mc Donnell, 2007; Wakefield \& Blodgett, 1996). The environment where individuals interact with such tangible and intangible variables, that is, the environment where the service encounter occurs is considered a servicescape.

A servicescape includes invisible communicational variables such as cultural attributes, interest and politeness of service employees in the service encounter as well as visible variables such as decoration, design and use of colours (Durna et al., 2015). Environmental psychologists emphasize that the complicated and strong influence of subcognitive components, which individuals are not aware of but which directly influence them and multiply by accumulation, should not be ignored when examining the effects of environment on human behaviours (Namasivayam \& Lin, 2008). Tombs and McColl-Kennedy (2003) underlined that a servicescape involves not only tangible clues and a designed structure but also a social meaning.

An analysis of the literature on the subject shows that the influence of environmental variables on behaviours of individuals was dealt with on the basis of certain variables (such as music, lighting, smell). Additionally, it has not yet been sufficiently understood how the emotional states 
and behavioural responses of guests are influenced by environmental variables, especially in hotel businesses. The main purpose of this study is to reveal the influence of environmental variables in hotel businesses on the emotional states and behavioural responses of guests. It appears that in the literature the influence of environmental components on individuals is more focused on store atmosphere (Chen \& Hsieh, 2011; Donovan \& Rossiter, 1982; Machleit \& Eroglu, 2000) and on restaurant servicescape (Ellen \& Zhang, 2014; Lin \& Mattila, 2010). The current study, which addresses as a whole the interaction between individuals and the environmental components that form the servicescape of hotel businesses, makes a significant contribution by filling this gap in the literature.

The contribution of the current study to the literature can be assessed in three main aspects. The first of these is the effort made for determining the environmental components that comprise the servicescape of hotel businesses on the emotional states of individuals. Another aspect is the determination of how the emotional states that individuals experience in any situation are reflected in their service experiences along with environmental variables. The influence of the first two items (environmental variables and emotional states) on behavioural intentions is another aspect of the study's contribution.

\section{Literature review}

The influence of environmental components on the behaviours of individuals is the main subject that is discussed by environmental psychologists. Scientists found out that individuals are directly or indirectly influenced by the components of an environment they visit and that this interaction guides their behaviours (Bitner, 1992; Liu \& Jang, 2009). The research in the field of environmental psychology has created a literature about cognitive and affective variables as the mediator components of environmental stimulants and behaviours. The study in which Mehrabian and Russell (1974) explained the influence of environment on individuals by the model they created is the basis of this newly emerged literature (Bell, 1999).

Mehrabian and Russell defined environmental psychology as "the direct influence of physical stimulants on the emotions of individuals and the influence of physical stimulants on various behaviours such as work performance and social interaction" (Countryman \& Jang, 2006, p. 535). Based on this definition, they developed a theoretical model, which they called the SOR (StimuliOrganism-Response) model. According to the model, environmental stimulants (S) result in emotional responses in individuals $(\mathrm{O})$ and these responses of individuals lead to behavioural outputs (R) (Donovan \& Rossiter, 1982; Jang \& Namkung, 2009).

Different components such as internal and external architecture and lighting comprised by the servicescape of a company are examples of stimulants. Once received and processed by an individual, a stimulant can guide expectations and perceptions regarding the servicescape of a company (Hoffman \& Bateson, 2011).

In the model, the responses of individuals to the physical environment are measured based on three variables: (1) Pleasure, (2) Arousal and (3) Dominance. Pleasure refers to the emotional states of individuals such as happy or unhappy, comfortable or uncomfortable while arousal refers to their emotional states such as excited or calm, and dominance refers to the emotional states such as controlling or being controlled, overpowering or obedient (Foxall \& Greenley, 1999, p. 149). Mehrabian and Russell claimed that all responses towards environment result in the behaviour of approach or avoidance. The approach/avoidance behaviour results in four different ways (Donovan \& Rossiter, 1982):

(1) A desire to stay in (approach) or to get out of (avoid) the environment.

(2) Interacting with the environment and exploring new things (approach) or ignoring (avoidance). 
(3) Getting in contact with other individuals in the environment (approach) or abstaining from interaction with other individuals (avoidance).

(4) The degree of enhancement (approach) or hindrance (avoidance) of performance and satisfaction with task performances.

\section{Servicescape}

The environmental stimulants referred to as servicescapes or service settings by Bitner (1992) are the components, which Kotler (1973) calls atmospherics, that is, components found in an environment where individuals interact with the environment. Servicescape refers to an environment, which is designed so as to produce the subject matter influence. The concept of servicescape expresses an environment where the interpersonal interaction emerges along with all the stages from the production of services to their delivery to consumers. Mathwick, Malhotra, and Rigdon (2001) call this concept as interactive theatre.

According to the servicescape model, a servicescape consists of three components: (a) ambient conditions, (b) spatial layout and functionality, (c) signs, symbols and artificial materials. Ambient conditions include variables that appeal to the senses of individuals such as temperature, lighting, noise, music and smell. Spatial layout and functionality refers to those arrangements to be made for operationalizing service delivery and enabling easier utilization of equipment in a service setting. Signs, symbols and artificial materials involve clues, which service providers offer to service beneficiaries as guidance (Tombs \& McColl-Kennedy, 2003). Dimensions of a servicescape influence consumers' perceptions about a service setting and their internal and external responses (Wakefield \& Blodgett, 1996). These dimensions can also be used as an effective tool for ensuring that consumers embrace a company's image and goals (Bitner, 1992).

Studies conducted to determine the effects of environmental components on the qualities and satisfaction in a service setting (Bitner, 1990), consumers and employees (Bitner, 1992), buying behaviour (Mattila \& Wirtz, 2001; Turley \& Milliman, 2000), the emotional and cognitive states of consumers (Brunner-Sperdin, Peters, \& Strobl, 2012; Namasivayam \& Mattila, 2007), positive and negative emotions of consumers (Ellen \& Zhang, 2014; Jang \& Namkung, 2009; Lin \& Liang, 2011) and consumer impressions (Countryman \& Jang, 2006) contain significant findings suggesting that physical evidence can be utilized as an effective marketing tool in different service settings.

The capacity of environmental components to influence behaviours and shape an image comes to light more distinctly, especially in service businesses. One of the most important reasons for this is the fact that production and consumption of services take place simultaneously and that consumers are in the factory (Bitner, 1992) when they are experiencing the service offered as a whole by a company. In the factory, intangible services are delivered to consumers. Consumers evaluate these intangible components because of their interaction with tangible components surrounding them. Satisfaction about this interaction is silent, and it is only noticed when an absence of environmental components is felt. Another reason is that environmental components influence a company's employees as much as consumers. Especially in service businesses, understanding the influence of physical components on the quality and nature of the social interaction between customers and employees is important for this reason (Bitner, 1992; Levitt, 1981). In fact, a servicescape influences not only the behaviours of individuals but also their cognitive, emotional and psychological states (Durna et al., 2015).

\section{Emotional states: pleasure and arousal}

Studies on synaesthesia (perception independent of stimulants), psychological interaction and semantic differences indicate the existence of fundamental response dimensions that go beyond even sensory approaches. In this context, emotional interactions can be thought of as the seed of individuals' responses to their environment (Mehrabian \& Russell, 1974). 
An individual's behaviour in a certain environment is formed through their emotions that are triggered by their environment. The first emotional reaction of an individual in an environment will also influence their subsequent behaviours. Ittelson (1973) mentioned that the first response of an individual to their environment is emotional. Accordingly, the direct emotional effect arising in response to a situation guides the instructions that are formed because of the subrelations established with the environment. Küller (1991) stated that the emerging emotion is not a phase but that it contains a quality, which evolves at every stage in an emotional process. When individuals are subjected to more intense emotional experiences, they come under more influence psychologically. Psychological changes related to emotions arise by a trigger of the nerve cells in the limbic system. It is believed that certain regions of the limbic system (like the intermediate cerebral region above the hypophysis) are connected with nerve cells that are directly related to emotions, especially to stronger emotions such as fear, anxiety, anger and stress (Amedeo, 1993).

The responses of individuals towards variables in different environments are caused by the differentiation in their emotions (Chen \& Hsieh, 2011). Mehrabian and Russell (1974) explained this interaction between emotions and behaviours in three dimensions (being satisfied or not, the level of being aroused, and being dominant or resigned). The reaction that arises because of individuals' interactions with their environment represents the emotional responses that momentarily occur in the inner world of individuals. As the subject matter environment leads to such emotional reactions in individuals, it is described by expressions like stressful, peaceful, lively or disgusting (Russell \& Mehrabian, 1978; Russell \& Pratt, 1980).

The state of being satisfied or not can either be directly understood from individuals' own words or from their facial expressions such as smiling or pouting. The state of being aroused refers to various emotional states between drowsing and getting overexcited. Although individuals' state of being aroused consists of an inner process, it can also be determined by such components as facial expressions, by verbal expressions or by the quality of expressions and speech tone. The state of being dominant or not refers to the penetration of the opposite party by the effect which is desired to be created through stimulants because of the interactions between individuals and stimulants. The state of being dominant or not can be understood by the position taken by the bodies of individuals, and it emerges independently of the state of being satisfied or not, or being aroused (Mehrabian \& Russell, 1974). The results of the studies show that the state of dominance does not significantly influence the behaviours of individuals in those service settings with a commercial nature (Donovan \& Rossiter, 1982; Russell \& Pratt, 1980). Additionally, tangible clues (such as the state of relaxation) are needed in order to be able to make determinations about the domination of individuals because of an interaction with a setting. Researchers can only determine such clues by observation or direct involvement in the process. So, as this study takes hotel businesses as its field of application and includes quantitative analyses, dominance was excluded from the evaluations because only observation technique or direct involvement of authors to the process may make it possible to determine such an effect which calls being dominant.

Individuals develop inner responses because of their being influenced by the variables of an environment they stay. These responses emerge because of the interaction between cognitive processes, which are shaped by the influence of many variables such as previous experiences and personality traits and emotional states. The current study is focused not on the relationship between cognitive processes and emotional responses but on conclusions about the kinds of emotional states and subsequently on behavioural evaluations that the environmental components in hotel businesses cause in individuals. Booms and Bitner (1982) argued that the emotional needs and reactions of individuals at a specific period can be determined in such environments, which are equipped with intense or plain environmental stimulants. The servicescape of hotel businesses allow evaluations about such reactions because of both the network of interaction it harbours and also the environmental stimulants available in the setting. The following hypotheses were made 
about the emotional states of individuals that occur because of their interaction with the environmental stimulants in the servicescape of hotels:

H1: Servicescape has a positive effect on emotional states.

H1a: Servicescape has a positive effect on positive emotional states.

H1b: Servicescape has a negative effect on negative emotional states.

\section{Behavioural responses}

Behavioural responses of individuals include the approach-avoidance behaviours, which are described as the intention of being present in a certain environment or deserting it. The approaching behaviour refers to an individual's being positively influenced from their environment upon completing the sequential stages of staying in an environment, exploring it, interacting with it and giving a meaning to it, resulting in an intention to come to the same environment again. The avoidance behaviour, on the other hand, means leaving an environment without the intention of returning due to being unsatisfied and feeling anxious or bored. Responses in an environment begin because of environmental factors, and responses of individuals can be predicted based on this environmental interaction (Chen \& Hsieh, 2011). When behavioural responses are thought of as a phenomenon that involves certain sequential processes of interacting with an environment, exploring it, giving a meaning to it, and revisiting or deserting it based on the emotions developing about it, then it can be considered that this phenomenon will also provide useful clues in a servicescape (Tsaur, Luoh, \& Syue, 2015).

Before making any judgment about a servicescape, individuals remember the emotional clues regarding their previous experiences and they make an evaluation upon visualizing a subcognitive image of the environment in their minds. The evaluation of an individual about a servicescape is rooted in themselves, their environment, and the interaction between the two. Although the quality of this interaction is determined largely by the influence of the variables in the environment, many different variables such as biological structure, personality traits and sociocultural experiences also play a role in the interaction (Lin, 2004). Mattila and Wirtz (2001) pointed out that the overall evaluations of individuals about their service experiences are based on environmental components as experienced in their subconscious minds and that approach/avoidance behaviours emerge as a result. Similarly, Nguyen and Leblanc (2002) said that the environmental conditions of a servicescape are a triggering element in the service conceptions of individuals and those attitudes and behaviours towards a service provider are influenced by environmental conditions.

The fact that individuals are influenced by the variables of an environment makes it necessary to transform servicescape, which involves a continuous circulation and a variable quality, into an impressive scene (Turley \& Milliman, 2000). A properly designed atmosphere will positively influence the intentions of consumers for patronage and usage patterns (McGoldrick \& Pieros, 1998). Designing an attractive servicescape also means making a positive impression on the emotions of individuals and steer their behaviours (Booms \& Bitner, 1982; Namasivayam \& Lin, 2008).

In this study, the following hypotheses were made to determine the influence of the emotional states of individuals that emerge as a result of their interactions with environmental stimulants on their approach/avoidance behaviours:

H2: Emotional states have a positive effect on behavioural intentions.

H2a: Positive emotional states cause approach behaviours. 
H2b: Negative emotional states cause avoidance behaviours.

H3: Servicescape has a positive effect on behavioural intentions.

\section{Mediating role of emotional states}

It is expected that individuals should be established emotional bonds with the service environment. This bond can be achieved through positive emotional states. Research on the effects of servicescape on behavioural intentions suggests that service environment can produce positive emotional states and overall impressions in the service environment (Jang \& Namkung, 2009; Jani \& Han, 2015). Although the direct effects of servicescape on emotional states and behavioural responses were to be handled, studies addressing the mediating role of positive and negative emotional states in the interaction between the service environment and behavioural responses are rather limited. Ang, Leong, and Lim (1997) found that pleasure mediates the effects of environmental factors on consumer behaviour. Sherman, Mathur, and Smith (1997) suggest that consumer's emotions can be a mediating factor in the purchase process. Walsh, Shiu, Hassan, Michaelidou, and Beatty (2011) confirmed that two emotions of pleasure and arousal differently mediate the relationship between store-related cognitions and behaviours. Nusairat, Akhorshaideh, Rashid, Sahadev, and Rembielak (2017) indicate that pleasure and cognition mediate the effect of social cues on behavioural responses.

From this point of view, to fill this research gap, we postulate that emotional states mediate the servicescape-behavioural responses relationship in hotel servicescape. Hence, we hypothesize the following:

H4: Emotional states mediate the relationship between servicescape and behavioural responses.

H4a: Positive emotional states have a mediating role in same direction.

H4b: Negative emotional states have a mediating role in same direction.

\section{Methodology}

In this descriptive study, the questionnaire form, which was utilized to obtain data, consists of three parts. The first part includes statements about environmental variables existing in a servicescape that were prepared by drawing upon a study by Jang and Namkung (2009). In the two other parts of the questionnaire form, Richins's (1997) Scale of Customer's Internal Responses, and Donovan and Rossiter's (1982) Scale of General Approach/Avoidance Intentions was used.

The environmental variables in a servicescape consist of 28 statements including those, which appeal to the sight/vision, hearing/audition, touch, smell/olfaction and taste senses of individuals. The scale of emotional states with 10 statements consists of the subscales of pleasure and arousal, which include positive/negative statements in themselves. The subscale of pleasure contains five different positive statements including satisfied, relaxed, rejuvenated, catered and joyful, while the subscale of arousal contains five different negative statements including stagnant, furious, dispirited, frightened and shy. The approach/avoidance behaviours emerging as a result of emotional interaction.

The convenience sampling method was utiliszed for accessing the research sample. The application was carried out on 400 hotel guests who visit Antalya. However, 211 questionnaire were analysed due to reasons such as incomplete coding or refusing to participate in the research. In the application process, hotel guests who experienced the service atmosphere of a hotel business for at least two nights were specifically selected. The purpose here is to ensure that guests are given sufficient time for the meeting of needs and creation of a social interaction and entertainment environment. 
To determine any possible effects of servicescape and emotional states on behavioural intentions, scale reliability is tested with Cronbach's Alpha coefficient. Based on the results, the scale is reliable since its Cronbach's Alpha coefficient is $90.8 \%$ for 43 items. Further analyses of the study consist of Correlation and Regression analyses due to the fact that the data is not suitable for SEM analyses [goodness of fit index (GFI) and comparative fit index (CFI) values are lower than 0.90] to measure direct and indirect effects simultaneously. Within this scope, emotional states of the participants are accepted as the dependent variable and servicescape is considered as an independent variable. In the ongoing process, behavioural intentions of the participants have added to the Regression model as a dependent variable, while servicescape has considered as an independent variable and emotional states are the mediator.

\section{Results}

The first findings of the study consist of Correlation analyses. From Table 1, it is clear that the participants highly consider the environmental stimulants existing in a servicescape ( $\bar{x}: 4.27)$, and in the sequel, they have some response-emotional reactions ( $\overline{\mathrm{x}}: 4.06)$. As a result, they exhibit some behaviours such as continuing to experience service, staying in the environment or being satisfied with the service. Findings of the study also confirm that displaying those kinds of behaviours that are based on responses correlated with environmental stimulants ( $\mathrm{r}$ : 0,635, p: 0.000). Further, positive emotional states of the participants are also correlated with the stimulants ( $r$ : 0,558, p: 0.000) considering the fact that they are the reflections of personal evaluations about some physical evidences. Meanwhile, correlation coefficients indicate that the negative emotional states of participants are related to the stimulants ( $\mathrm{r}:-0,221, \mathrm{p}: 0.000)$. In other words, even displeasure (broodiness, discontentedness, etc.) and arousal (calmness, nerviness, etc.) are related to environmental stimulants. Still, those relations do not verify any possible effect of stimulants or customer's internal responses (emotions) on behavioural responses. Thus, ongoing section consists Regression modelling phase.

In Regression analysis, direct effects are tested with bivariate and multivariate Regression analysis and to test the mediating effect of positive and negative emotions of participants Baron and Kenny's (1986) approach is adopted. Baron and Kenny's approach predicts to occur three main conditions (Baron \& Kenny, 1986, p. 1176):

(a) Variations in levels of the independent variable significantly account for variations in the presumed mediator.

(b) Variations in the mediator significantly account for variations in the dependent variable.

(c) When paths a and b are controlled, a previously significant relation between the independent and dependent variables is no longer significant, with the strongest demonstration of mediation occurring when Path $c$ is zero.... When Path $c$ is reduced to zero, we have strong evidence for a single, dominant mediator. If the residual Path $c$ is not zero, this indicates the operation of multiple mediating factors.

Findings in Table 2 indicate that servicescape strongly and significantly influences positive emotional states of the participants ( $(0.783$, p: 0.000) meanwhile those stimulants also negatively affect some emotional states ( $B$ : $-0.371, \mathrm{p}: 0.000$ ). That kind of negative effect could cause from

Table 1. Means, standard deviations and correlation coefficients.

\begin{tabular}{|c|c|c|c|c|c|c|}
\hline & Mean & Standard deviation & Servicescape & Emotional positive & Emotional negative & Behavioural \\
\hline Servicescape & 4.256 & .512 & 1 & & & \\
\hline Positive Emotional States & 4.052 & .717 & $.558 * *$ & 1 & & \\
\hline Negative Emotional States & 1.506 & .858 & $-.221^{* *}$ & -.113 & 1 & \\
\hline Behavioural Reponses & 4.227 & 677 & $.635^{* *}$ & $.674^{* *}$ & $-.234^{* *}$ & 1 \\
\hline
\end{tabular}


Table 2. The effects of servicescape (stimulants) on emotions.

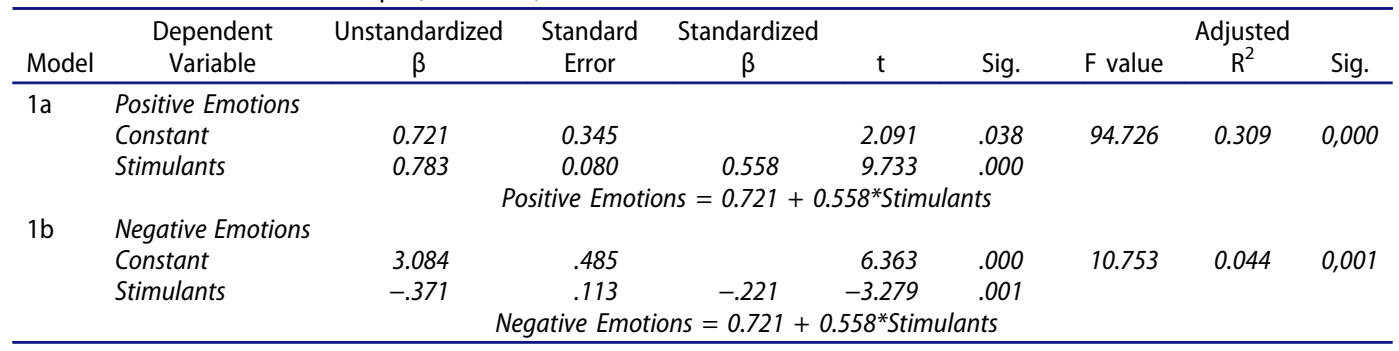

the differences in the perceptions of the participants. For instance, one may be annoyed with lighting or music contrary to the consensus among others.

In Table 3, the direct effects of emotional states on behavioural responses were measured. With the $47.5 \%$ variance ratio, each increment observed at positive emotional states of participants contributes to behavioural responses at the rate of $62 \%$, while negative states have a decreasing effect ( $:-0.127)$. In other words, positive and negative emotional states significantly affect the behavioural responses of participants.

Although servicescape has significant influences on behavioural responses, the emotional states of participants could change the degree of influence on behavioural responses as a mediator. To validate this assumption, Model 3 was generated (Table 4). According to Model 3, servicescape increase behavioural responses at the rate of $46.6 \%$, the contribution of positive emotional states to behavioural responses is $44 \%$, and, negative emotional states have a non-linear contribution to behavioural responses $(-0.08 \%)$. As stated before, the direct effect of stimulants on behavioural responses is 0.841 ; however, this direct effect decreases to 0.466 when emotional states are counted in the Regression model. So we can conclude that emotional states of participants have a mediating effect on the relation between stimulants and behavioural responses. In addition, these results indicate the operation of multiple mediating factors instead of a dominant mediator since the Path $\mathrm{c}$ is not reduced to zero (Figures 1 and 2).

Table 3. The effects of emotional states on behavioural responses.

\begin{tabular}{|c|c|c|c|c|c|c|c|c|c|}
\hline Model & $\begin{array}{c}\text { Dependent } \\
\text { Variable }\end{array}$ & $\begin{array}{c}\text { Unstandardized } \\
\beta \\
\end{array}$ & $\begin{array}{c}\text { Standard } \\
\text { Error }\end{array}$ & $\begin{array}{c}\text { Standardized } \\
\beta \\
\end{array}$ & $\mathrm{t}$ & Sig. & $F$ value & $\begin{array}{c}\text { Adjusted } \\
\mathrm{R}^{2} \\
\end{array}$ & Sig. \\
\hline \multirow[t]{5}{*}{2} & $\begin{array}{l}\text { Behavioral } \\
\text { Responses }\end{array}$ & & & & & & & & \\
\hline & Constant & 1.906 & 0.211 & & 9.043 & 0.000 & 95.954 & 0.475 & 0.000 \\
\hline & Positive Emotions & 0.620 & 0.048 & 0.656 & 13.036 & 0.000 & & & \\
\hline & Negative Emotions & -0.127 & 0.040 & -0.160 & -3.186 & 0.002 & & & \\
\hline & \multicolumn{9}{|c|}{ Behavioral responses $=1.906+0.656^{*}$ Positive Emotions $-0.160 *$ Negative Emotions } \\
\hline
\end{tabular}

Table 4. Testing the mediating effects of emotional states.

\begin{tabular}{|c|c|c|c|c|c|c|c|c|c|}
\hline Model & $\begin{array}{l}\text { Dependent } \\
\text { Variable }\end{array}$ & $\begin{array}{c}\text { Unstandardized } \\
\beta\end{array}$ & $\begin{array}{l}\text { Standard } \\
\text { Error }\end{array}$ & $\begin{array}{c}\text { Standardized } \\
\beta\end{array}$ & $\mathrm{t}$ & Sig. & $F$ value & $\begin{array}{l}\text { Adjusted } \\
\mathrm{R}^{2}\end{array}$ & Sig. \\
\hline \multirow[t]{4}{*}{3} & $\begin{array}{l}\text { Behavioral } \\
\text { Responses }\end{array}$ & & & & & & & & \\
\hline & Constant & 0.648 & 0.303 & - & 2.136 & 0.034 & 141.329 & 0.401 & 0.000 \\
\hline & Stimulants & 0.841 & 0.071 & 0.635 & 11.888 & 0.000 & & & \\
\hline & Behavioral response & $s=0.648+0.635$ & Stimulants & & & & & & \\
\hline \multirow[t]{6}{*}{$3 a$} & $\begin{array}{l}\text { Behavioral } \\
\text { Responses }\end{array}$ & & & & & & & & \\
\hline & Constant & .584 & .288 & & 2.031 & .044 & 88.535 & 0.556 & 0.000 \\
\hline & Stimulants & .466 & .075 & .352 & 6.230 & .000 & & & \\
\hline & Positive Emotions & .440 & .052 & .466 & 8.400 & .000 & & & \\
\hline & Negative Emotions & -.082 & .037 & -.104 & -2.204 & .029 & & & \\
\hline & Behavioral $\mathrm{R}$ & esponses $=0.584$ & $0.352 *$ Stim & lants $+0.466^{*}$ & ositive el & tions - & $04^{*}$ nega & emc & \\
\hline
\end{tabular}


We also performed SOBEL test (Preacher \& Leonardelli, 2001) in order to determine the significance of the mediator effect (Tables 5 and 6). Sobel test results in Table 5 confirm that positive emotional states of participants have a significant effect on behavioural responses; meanwhile, it is a mediator between servicescape (stimulants) and behavioural responses of participants (z: 7.800, p: 0.000, p < 0.05). On the other hand, negative emotional states are not a mediator since the significance level is higher than 0.05 (p: 0.067). Results obtained from SOBEL test support H4a hypothesis in which referring positive emotional states is a mediator between servicescape and behavioural responses. In sum, it is concluded

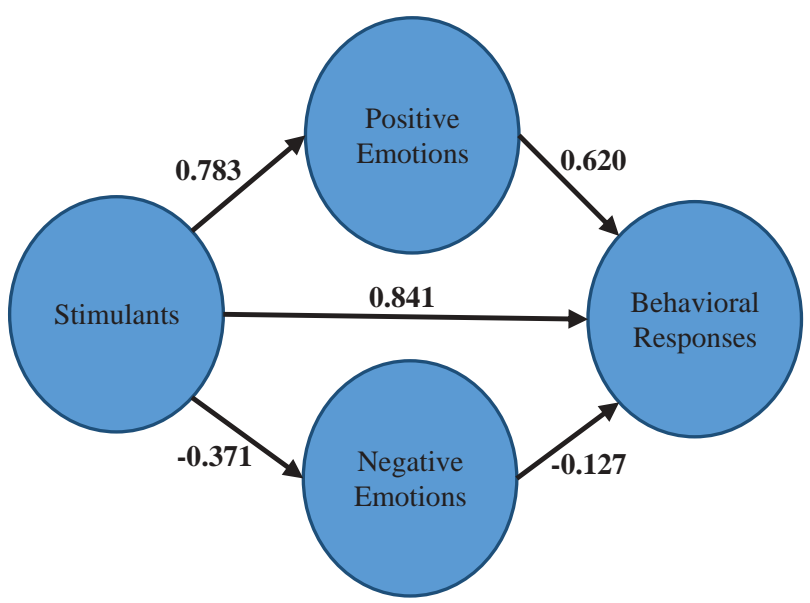

Figure 1. Direct effects of positive and negative emotions on behavioural responses.

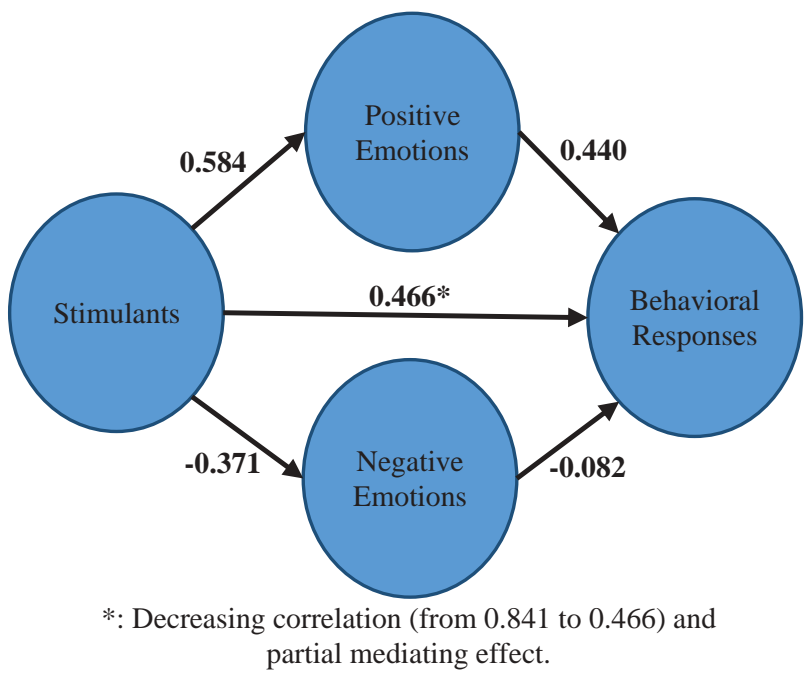

Figure 2. Mediating effects of positive and negative emotions.

Table 5. Sobel test for positive emotions' mediating effect.

\begin{tabular}{lllccc}
\hline & Input & & Test statistic (z) & Std. Error & p-value \\
\hline$a$ & 0.783 & Sobel test: & 7.80091539 & 0.062 & 0.000 \\
$b$ & 0.620 & Aroian test: & 7.78610644 & 0.062 & 0.000 \\
$S_{a}$ & 0.080 & Goodman test: & 7.81580916 & 0.062 & 0.000 \\
$S_{b}$ & 0.048 & & & & \\
\hline
\end{tabular}


Table 6. Sobel test for negative emotions' mediating effect.

\begin{tabular}{cccccc}
\hline & Input & & Test statistic $(\mathrm{z})$ & Std. Error & $\mathrm{p}$-value \\
\hline $\boldsymbol{a}$ & -0.371 & Sobel test: & 1.83689081 & 0.017 & 0.067 \\
$\boldsymbol{b}$ & -0.082 & Aroian test: & 1.78101431 & 0.017 & 0.075 \\
$S_{a}$ & 0.113 & Goodman test: & 1.89837954 & 0.016 & 0.058 \\
$S_{b}$ & 0.037 & & & & \\
\hline
\end{tabular}

Table 7. Results of hypotheses.

\begin{tabular}{lllrr}
\hline Hypotheses & & & B & Result \\
\hline $\mathrm{H} 1$ & $\mathrm{H} 1 \mathrm{a}:$ Servicescape $\rightarrow$ & Positive Emotional States & .78 & Supported \\
& $\mathrm{H} 1 \mathrm{~b}:$ Servicescape $\rightarrow$ & Negative Emotional States & -.37 & Supported \\
$\mathrm{H} 2$ & $\mathrm{H} 2 \mathrm{a}:$ Positive Emotional States $\rightarrow$ & Approach Behaviors & .62 & Supported \\
& $\mathrm{H}$ 2b: Negative Emotional States $\rightarrow$ & Avoidance Behaviors & -.13 & Supported \\
$\mathrm{H} 3$ & $\mathrm{H} 3:$ Servicescape $\rightarrow$ & Behavioral Responses & .84 & Supported \\
$\mathrm{H} 4$ & H4a: Positive Emotional States & Mediator & .44 & Supported \\
& H4b: Negative Emotional States & Mediator & $-.08^{*}$ & Rejected \\
\hline
\end{tabular}

${ }^{*}$ Correlation is not significant, $p>.05$

that servicescape positively influences behavioural responses, and positive emotional states of the participants significantly mediate this effect as seen in Table 7.

\section{Conclusion and implications}

In the study, it was found out that servicescape positively influence behavioural responses, and individuals' emotional states play a mediating role in the process of this influence.

According to the findings, servicescape accounts for $84 \%$ of the change in the behavioural responses of individuals. The study in which Mehrabian and Russell (1974) explained the influence of the environment on individuals contains important findings regarding the necessity of considering cognitive and sensory variables as a mediating component of environmental stimulants and behaviours. Based on this, emotional states were also included in the Regression model as the mediating variable. According to the findings, one unit of change under the influence of servicescape increased positive emotional states of individuals by $78 \%$ while decreasing negative emotional states by $37 \%$.

Within the scope of the research, servicescape and positive and negative emotional states, respectively, were included in the Regression model, and the influence of emotional states along with servicescape was analysed in order to determine the extent at which behaviours of individuals are influenced by their emotional states that arise as a result of their being influenced by servicescape, and to take this influence in consideration of all variables. Accordingly, servicescape alone accounts for $84 \%$ of the behavioural responses. When positive emotional states were also included in this interaction, it was found that behavioural responses were influenced at a level of $46.6 \%$ by servicescape, at $44 \%$ by positive emotional states and non-linearly $(-0.08 \%)$ by negative emotional states.

The findings of how a servicescape influences behavioural responses along with developing emotional states tally with the findings of the studies in the literature (Chang, 2016; Jani \& Han, 2015; Ryu \& Jang, 2007). In a study where Ali and Amin (2014) affirmed that higher perceptions of the guests' about physical environment lead to positive emotions and, consequently behavioural intentions. Jani and Han (2015) affirmed the effect of hotel ambience on guests' emotions and state that these emotions have a significant effect on loyalty. In another study, Babin and Attaway (2000) demonstrated that such positive emotional states as excitement, happiness and satisfaction have a certain relationship with hedonic and utilitarian consumption behaviours. Lee, Guillet, and Law (2018), suggested that the most dominant dimension of emotional wellness is calmness. Similarly, in this study, it is seen that positive emotional states (pleasure or arousal) of individuals express a significant part of their behavioural responses. 
The emotional states of individuals in a servicescape influence both their attitudes and behaviours in service encounter and their judgments about the image of a subject matter business. In fact, Countryman and Jang (2006) ascertained that atmosphere components significantly influence the overall impression of consumers about a servicescape. Similarly, Dedeoğlu, Küçükergin, and Balıkçığlu (2015) indicated that servicescape perceptions of tourists have a significant effect on value, image and pleasure. The findings of both the studies in the literature and of this current study provide important clues suggesting that rendering a servicescape more functional and useful for its users will produce many advantages for businesses. In this context, it is important to take the interaction in a servicescape into consideration in terms of stimulants and emotional states.

The reactions/responses of individuals towards an event or a fact are manifested because of their internal responses. Booms and Bitner (1982, p. 39) reported that the emotional needs and reactions of individuals at a specific period can be determined in environments which are equipped with intense or plain environmental stimulants. The level and nature of the stimulants can be seen as a component, which can be utilized to understand the emotional responses of guests. Thus, determining the emotional states will ensure that the related servicescape is designed by considering those emotional states. While creating a servicescape, hoteliers should also consider findings of academic studies and expert designers. In this process, designers' interest in human psychology, as well as their technical knowledge, should be taken into consideration. Many physical and non-physical components such as artworks, personnel in charge and manner of presentation are used together for ensuring that a servicescape gains a personality (such as sympathetic, ostentatious). It is expected that guests establish positive emotional bonds with servicescape with a personality (Avan \& Özdemir, 2015). The findings of both the current study and the other studies in the literature (Babacan, 2010; Rosenbaum \& Massiah, 2011) show that guests establish a positive emotional bond with a servicescape. It should be remembered when creating a servicescape that just like humans, a servicescape has a personality and that a capacity of communication is added to non-tangible components by design and equipment. What is actually intended here is to give subconscious messages to guests? In the case, guests receive these subliminal messages rightly; they will perceive that the servicescape is successfully designed.

Although the influence of environmental variables on behaviours is studied in the literature, the number of those studies, which attempt to determine what kind of results this influence brings in servicescape of hotel businesses, is very limited. In order to reveal this influence, the kinds of emotional states and behavioural responses that are caused in individuals by the servicescape should be examined by separately addressing the effects of each variable. Additionally, studies in which experimental methods are used, in particular, are needed in order to determine the emotional states that a servicescape leads to in individuals.

\section{Disclosure statement}

No potential conflict of interest was reported by the authors.

\section{Notes on contributors}

Ali Avan is an assistant professor in Tourism Management and has received his $\mathrm{PhD}$ in Business Administration. His areas of research include consumer behaviour in tourism, services marketing and sustainability in tourism.

Ahmet Uyar is an assistant professor of marketing and has received his $\mathrm{PhD}$ in Business Administration. His areas of interest include consumer behaviour, customer relationship management and innovation in marketing.

Özcan Zorlu has received his associate professorship in Tourism and his $\mathrm{PhD}$ in Business Administration. He has written widely on specifically organizational behaviour and knowledge management in tourism.

Alparslan Özmen is an assistant professor of marketing and has written mainly on services marketing and brand management. 


\section{ORCID}

Ali Avan (D) http://orcid.org/0000-0003-4510-3962

\section{References}

Ali, F., \& Amin, M. (2014). The influence of physical environment on emotions, customer satisfaction and behavioural intentions in Chinese resort hotel industry. Journal of Global Business Advancement, 7(3), $249-266$.

Amedeo, D. (1993). Emotions in person-environment-behavior episodes. In T. Garling \& R. G. Golledge (Eds.), Behavior and environment: Psychological and geographical approaches (pp. 83-116). Amsterdam: Elsevier.

Ang, S. H., Leong, S. M., \& Lim, J. (1997). The mediating influence of pleasure and arousal on layout and signage effects. Journal of Retailing and Consumer Services, 4(1), 13-24.

Ariffin, H. F., Bibon, M. F., \& Abdullah, R. P. S. R. (2011). Restaurant's atmospheric elements: What the customer wants. Journal of Asian Behavioural Studies, 1(2), 33-43.

Avan, A., \& Özdemir, Ş. (2015). Zincir otellerde hizmet ortamı-kullanıcı etkileşimi üzerine nitel bir araştırma [A qualitative research on service environment and user interaction in hotel chains]. Tüketici ve Tüketim Arastirmalari Dergisi, 7(1), 87-131.

Babacan, M. (2010, October). Mimari tasarımın tüketiciyle iletişimi: Alışveriș merkezleri örneği [Communication of architectural design with the consumer: A case on shopping malls]. In M. Tanyeri (Ed.), Proceedings of the 15. Ulusal Pazarlama Kongresi (pp. 1-23). İzmir: Dokuz Eylül Üniversitesi İşletme Fakültesi.

Babin, B. J., \& Attaway, J. S. (2000). Atmospheric affect as a tool for creating value and gaining share of customers. Journal of Business Research, 49(2), 91-99.

Baron, R. M., \& Kenny, D. A. (1986). The moderator-mediator variable distinction in social psychological research: Conceptual, strategic, and statistical considerations. Journal of Personality and Social Psychology, 51(6), 1173.

Bell, S. J. (1999). Image and consumer attraction to intraurban retail areas: An environmental psychology approach. Journal of Retailing and Consumer Services, 6, 67-78.

Bitner, M. J. (1990). Evaluating service encounters: The effects of physical surroundings and employee responses. Journal of Marketing, 54(2), 69-82.

Bitner, M. J. (1992). Servicescapes: The impact of physical surroundings on customers and employees. Journal of Marketing, 56(2), 57-71.

Booms, B. H., \& Bitner, M. J. (1982). Marketing services by managing the environment. Cornell Hotel and Restaurant Administration Quarterly, 23, 35-40.

Brunner-Sperdin, A., Peters, M., \& Strobl, A. (2012). It is all about the emotional state: Managing tourists' experiences. International Journal of Hospitality Management, 31(1), 23-30.

Chang, K. C. (2016). Effect of servicescape on customer behavioral intentions: Moderating roles of service climate and employee engagement. International Journal of Hospitality Management, 53, 116-128.

Chen, H.-S., \& Hsieh, T. (2011). The effect of atmosphere on customer perceptions and customer behavior responses in China store supermarkets. African Journal of Business Management, 5(24), 10054-10066.

Countryman, C. C., \& Jang, S. (2006). The effects of atmospheric elements on customer impression: The case of hotel lobbies. International Journal of Contemporary Hospitality Management, 18(7), 534-545.

Dedeoğlu, B. B., Küçükergin, K. G., \& Balıkçığlu, S. (2015). Understanding the relationships of servicescape, value, image, pleasure, and behavioral intentions among hotel customers. Journal of Travel \& Tourism Marketing, 32(1), S42-S61.

Donovan, R. J., \& Rossiter, J. R. (1982). Store atmosphere: An environmental psychology approach. Psychology of Store Atmosphere, 58(1), 34-57.

Durna, U., Dedeoglu, B. B., \& Balikcioglu, S. (2015). The role of servicescape and image perceptions of customers on behavioral intentions in the hotel industry. International Journal of Contemporary Hospitality Management, 27(7), 1728-1748.

Ellen, T., \& Zhang, R. (2014). Measuring the effect of company restaurant servicescape on patrons' emotional states and behavioral intentions. Journal of Foodservice Business Research, 17(2), 85-112.

Foxall, G. R., \& Greenley, G. E. (1999). Consumers' emotional responses to service environments. Journal of Business Research, 46(2), 149-158.

Hoffman, K. D., \& Bateson, J. E. G. (2011). Services marketing: Concepts, strategies, \& cases. Mason: South-Western Cengage Learning.

Ittelson, W. H. (1973). Environment and cognition. New York: Seminar Press.

Jang, S., \& Namkung, Y. (2009). Perceived quality, emotions, and behavioral intentions: Application of an extended Mehrabian-Russell model to restaurants. Journal of Business Research, 62(4), 451-460.

Jani, D., \& Han, H. (2015). Influence of environmental stimuli on hotel customer emotional loyalty response: Testing the moderating effect of the big five personality factors. International Journal of Hospitality Management, 44, 48-57.

Kotler, P. (1973). Atmospheric as a marketing tool. Journal of Retailing, 49(4), 48-64. 
Küller, R. (1991). Environmental assessment from a neuropsychological perspective. In T. Garling \& G. W. Evans (Eds.), Environment, cognition, and action: An integrated approach (pp. 111-147). New York: Oxford University Press.

Lee, A. H., Guillet, B. D., \& Law, R. (2018). Tourists' emotional wellness and hotel room colour. Current Issues in Tourism, 21(8), 856-862.

Levitt, T. (1981). Marketing intangible products and product intangibles. Harvard Business Review, 22(2), 37-44.

Lin, I. Y. (2004). Evaluating a servicescape: The effect of cognition and emotion. Hospitality Management, 23, $163-178$.

Lin, I. Y., \& Mattila, A. S. (2010). Restaurant servicescape, service encounter, and perceived congruency on customers' emotions and satisfaction. Journal of Hospitality Marketing \& Management, 19(8), 819-841.

Lin, J. C., \& Liang, H. (2011). The influence of service environments on customer emotion and service outcomes. Managing Service Quality, 21(4), 350-372.

Liu, Y., \& Jang, S. (2009). The effects of dining atmospherics: An extended Mehrabian-Russell model. International Journal of Hospitality Management, 28(4), 494-503.

Machleit, K. A., \& Eroglu, S. A. (2000). Describing and measuring emotional response to shopping experience. Journal of Business Research, 49(2), 101-111.

Mathwick, C., Malhotra, N., \& Rigdon, E. (2001). Experiential value: Conceptualization, measurement and application in the catalog and internet shopping environment. Journal of Retailing, 77(1), 39-56.

Mattila, A. S., \& Wirtz, J. (2001). Congruency of scent and music as a driver of in-store evaluation and behavior. Journal of Retailing, 77(2), 273-289.

McDonnell, J. (2007). Music, scent and time preferences for waiting lines. Journal of Bank Marketing, 25(4), $223-237$.

McGoldrick, P. J., \& Pieros, C. P. (1998). Atmospherics, pleasure and arousal: The influence of response moderators. Journal of Marketing Management, 14(1-3), 173-197.

Mehrabian, A., \& Russell, J. A. (1974). An approach to environmental psychology. London: The MIT Press.

Namasivayam, K., \& Lin, I. Y. (2008). The servicescape. In P. Jones (Ed.), Handbook of hospitality operations and IT (pp. 43-62). London: Butterworth-Heinemann.

Namasivayam, K., \& Mattila, A. S. (2007). Accounting for the joint effects of the servicescape and service exchange on consumers' satisfaction evaluations. Journal of Hospitality \& Tourism Research, 31(1), 3-18.

Nguyen, N., \& Leblanc, G. (2002). Contact personnel, physical environment and the perceived corporate image of intangible services by new clients. International Journal of Service Industry Management, 13(3), $242-262$.

Nusairat, N. M., Akhorshaideh, A. H. O., Rashid, T., Sahadev, S., \& Rembielak, G. (2017). Social cues-customer behavior relationship: The mediating role of emotions and cognition. International Journal of Marketing Studies, 9(1), 1-17.

Preacher, S., \& Leonardelli, G. (2001). Calculation for the Sobel test: An interactive calculation tool for mediation tests. Advance online publication. Retrieved from http://quantpsy.org/sobel/sobel.htm

Richins, M. L. (1997). Measuring emotions in the consumption experience. Journal of Consumer Research, 24(2), 127-146.

Rosenbaum, M. S., \& Massiah, C. (2011). An expanded servicescape perspective. Journal of Service Management, 22 (4), 471-490.

Russell, J. A., \& Mehrabian, A. (1978). Approach-avoidance and affiliation as functions of the emotion-eliciting quality of an environment. Environment and Behavior, 10(3), 355-387.

Russell, J. A., \& Pratt, G. (1980). A description of the affective quality attributed to environments. Journal of Personality and Social Psychology, 38(2), 311-322.

Ryu, K., \& Jang, S. S. (2007). The effect of environmental perceptions on behavioral intentions through emotions: The case of upscale restaurants. Journal of Hospitality \& Tourism Research, 31(1), 56-72.

Sherman, E., Mathur, A., \& Smith, R. B. (1997). Store environment and consumer purchase behavior: Mediating role of consumer emotions. Psychology \& Marketing, 14(4), 361-378.

Tombs, A., \& McColl-Kennedy, J. R. (2003). Social-servicescape conceptual model. Marketing Theory, 3(4), 447-475.

Tsaur, S.-H., Luoh, H.-F., \& Syue, -S.-S. (2015). Positive emotions and behavioral intentions of customers in full-service restaurants: Does aesthetic labor matter? International Journal of Hospitality Management, 51, 115-126.

Turley, L. W., \& Milliman, R. E. (2000). Atmospheric effects on shopping behavior: A review of the experimental evidence. Journal of Business Research, 49(2), 193-211.

Wakefield, K. L., \& Blodgett, J. G. (1996). The effect of the servicescape on customers' behavioural intentions in leisure service settings. The Journal of Services Marketing, 10(6), 45-61.

Walsh, G., Shiu, E., Hassan, L. M., Michaelidou, N., \& Beatty, S. E. (2011). Emotions, store-environmental cues, store-choice criteria, and marketing outcomes. Journal of Business Research, 64, 737-744. 